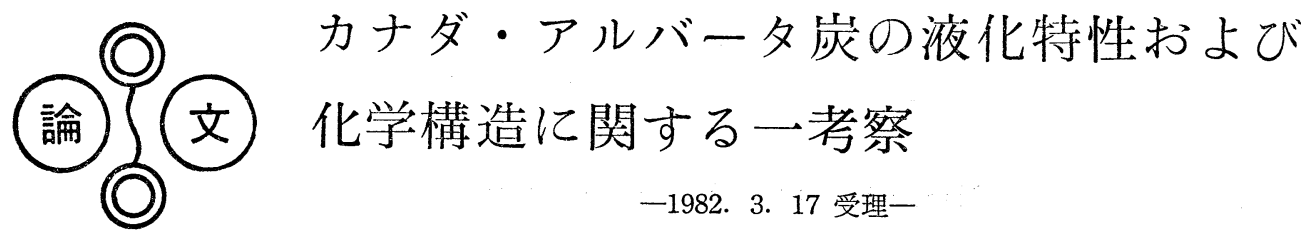

\author{
公害資源研究所 佐 藤 芳 樹* \\ Alberta Research Council Sujit K. CHAKRABARTTY**
}

\section{1. 緒言}

カナダの石炭資源はその約 $99 \%$ （確定理蔵量べー ス) ${ }^{122)}$ がいわゆる西部 3 州汇賦存して括り，とりわけ フルバータ州はカナダの全確定石炭理蔵量の約 $80 \%$, すなわち約 436 億 $\mathrm{t}$ の豊富な石炭資源を有している。 従来より発電用などとして年間1700〜2000万 $\mathrm{t} （ 1979$ 〜1980年）の石炭が生産されているもののこれらの量 は理蔵量に比較して非常に僅かであり, 今後の著しい 開発, 発展が期待される。本研究はアルバータ炭の 80 \%弱を占める亜瀝青炭のうちから代表的なるのとして Forestburg 炭を選び臨界ガス抽出液化反応などの実 験を行い, その液化特性拈よび化学構造についての検 討を試みたものである。

トルエンのような比較的低沸点の溶剤を臨界温度以 上に加熱し, ガス状溶剂によって石炭の抽出を行う臨 界ガス抽出法 ${ }^{3)}$ は約 $420^{\circ} \mathrm{C}$ 前後の反応温度で石炭を処 理し，比較的低分子 (分子量2000以下) で水素含有量 に富む抽出物を生成するなどの特徴を有している。英 国 National Coal Board(NCB)所属の Coal Research Establishment(CRE) に拮いては半連続装置なら びそ $5 \mathrm{~kg} / \mathrm{hr}$ の連続抽出装置を用いて抽出物の詳細な 構造解析を含さ基礎的研究と抽出物の水素化拉よび分 離方法の検討などを含めた工業的開発研究が数年来進 められている(4) 6) C REの研究によれば抽出物の収 量叔よび性状は溶剂により若干異なるが英国産低品位 炭をトルエンで処理した場合，収量は約 $27 \mathrm{wt} \%$, daf Coal base, C : $82 \%, \mathrm{H}: 7 \%$ 打よび平均分子量 410 の抽出物が得られて和り，さらに ${ }^{1} \mathrm{H}-,{ }^{13} \mathrm{C}-\mathrm{NMR}$ ス ペクトル，I Rースペクトルなぞを用いた構造解析に より各種溶剤によって分別された成分の平均化学構造 式を呈示している。しかし広い範囲の溶剤和よび触媒

\footnotetext{
* 資源第一部第一課 茨城県筑波郡谷田部町小野川16-3

** Coal Research Department
}

存在下での実験結果の報告は非常に少ない。

石炭の臨界ガス抽出法は所定の反応条件で生成した ガス状溶剤を利用し，比較的温和な石炭からの分解生 成物を抽出する反応過程として理解されており, 抽出 物は凝縮過程を経て回収される。抽出反応の温度が比 較的低く，抽出物の二次分解を防ぐことが出来るた め, 原料石炭中の有機化学構造を推測する有効な手段 としても知られている。

本研究では代表的な西部カナダ炭としてアルバータ 州産の亜歴青炭を取り上げ，トルェン秥よび各種アル コールなどの溶剤，ならびに塩化亜鉛掞よび塩化錫触 媒存在下, 臨界状態近い条件下での抽出実験, その 他一部，常法に上るテトラリンを溶剤とするオートク レーブ実験を行い, 抽出率, 抽出物の性状和よびその 化学構造などについての比較, 検討を試みた。

\section{2. 実験}

実験に供したカナダ・アルバータ州産 Forestburg Coal (Manalta-Vesta Mine) は常法により16〜24 ッシュに粉砕, 乾燥された。その元素分析値を Table 1 に示した。触媒として用いた塩化两鉛および塩化錫 ならびに各種溶剂は市販品をそのま使用した。また 触媒を含浸させた石炭試料の調整は次の手法飞従っ た。すなわち, 㐫らかじめ所定量の触媒を溶解させた メタノール溶液に石炭を浸し, その後メタノールを蒸 発, 乾燥し, さらに $110^{\circ} \mathrm{C} て ゙ 3$ 時間真空乾燥した。試 料中の石炭拉よび触媒の正確な重量は試料調整びんの 内壁に付着した触媒を再びメタノール溶解し，ろ過

Table 1 Analysis of Forestburg coal (Manalta-Vesta Mine, Alberta)

\begin{tabular}{ll} 
C (daf base, wt \%) & 73.5 \\
$\mathrm{H} \quad($ daf base, wt \%) & 4.7 \\
$\mathrm{H} / \mathrm{C}$ atmic ratio & 0.756 \\
Ash (dry coal base, wt \%) & 9.59 \\
\hline
\end{tabular}


の後, おのおの乾燥・科量して算出した。

反応情定床反応管 (内径 $1.27 \mathrm{~cm}$, 長さ $33 \mathrm{~cm}$ ), 各種溶剤を気化室に送入する為の高圧ポンプ, その他温度, 圧力および流量制御ならびに測定 装置などを備えた通常の高圧流通式装置Fig. 1 によって行った。実験に際しては石炭または触 媒を含浸させた石炭約 $4.5 \mathrm{~g}$ を反応管の所定の 位置に固定し，高圧テストを行ったのち外熱加 熱炉によって反応管を急熱した。350ㄷ まで加 熱するのに要した時間は約30分であった。一方 溶剤は $0.1 \sim 0.2 \mathrm{m \ell} / \mathrm{min}$ の速度でポンプによっ て $250^{\circ} \mathrm{C}$ に保たれた気化室に送られ，反応管温 度が $250^{\circ} \mathrm{C}$ に達した時点から送入を開始した。

反応によるガス状生成物は一定時間毎に装置 に直結された分離型ガスクロマトグラフによっ て分析され，なた液状生成物は溶剂とともに耐 圧ガラス製受器に捕集されたのち, やはり常法 に従ってガスクロマトグラフ分析に供された。 一方反応後, 反応管内に残った固体状生成物は

トルェンによるソックスレー抽出ののち, 抽出物につ いては前述の液状生成物と混合され，溶剂を蒸発，除

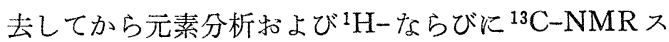
ペクトル分析に供された。最終的な全転化率はトルエ ン不溶物の重量に基ついて評価した。

実験は反応温度 $350^{\circ} \mathrm{C}$, 伴送ガス流量 $60 \mathrm{~m} \ell / \mathrm{min}$, 溶 剂の供給量 $0.1 \sim 0.2 \mathrm{ml} / \mathrm{min}$ (液体) 扎よび反応圧力 $6.8 \mathrm{~kg} / \mathrm{cm}^{2}$ ・Gの条件下で行われた。

補促的に試みられたオートクレーブ実験の方法など については次の項で記述する。

\section{3. 結果および考察}

溶剂, 触媒およびキャリヤーガスの種類を変えた実 験の結果をTable 2 に示した。無触媒反応で得られた 全転化率の值は溶剈の有無执よびキャリヤーガスの種 類に関係なく非常に低く6.5〜12.5 wt \%であった。溶 剤を用いない実験から得られたガス状生成物は $99 \%$ 以 上が炭酸ガスであり，その外に少量の一酸化炭素およ びメタンなどであり，多少の脱メチル基反応を伴った 脱炭酸反応が拈もに起こっているものと考えられる。 ただし溶剤を加えた実験では上記のガスに加えて石炭 に対して数\%程度の他のガスの生成が認められ, トル エン共存の場合にはメタンとベンゼンが, メチルアル コールでは一酸化炭素执よび水素，またイソプロピル アルコールではプロパンおよびプロピレンを検出した が，いずれも石炭の反応とは独立した溶剂自身の分解 反応と考えられた。

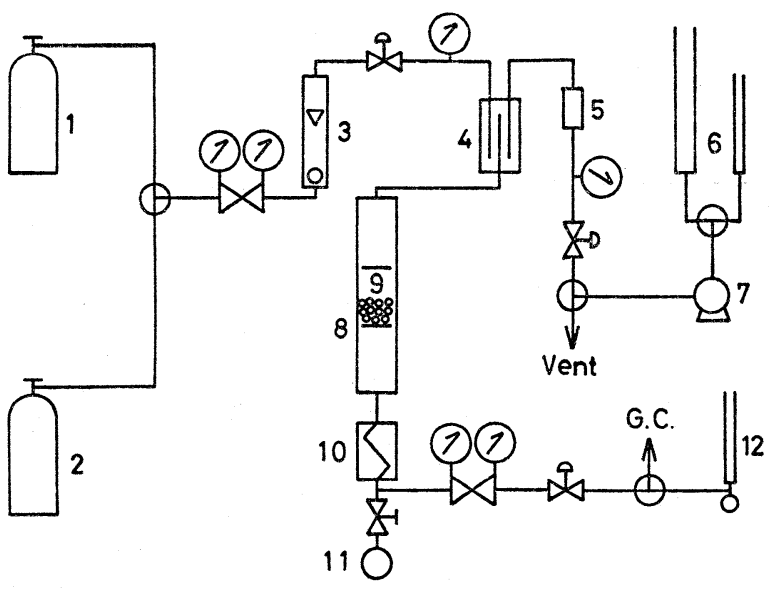

1. $\mathrm{H}_{2} \quad 2 . \mathrm{He}$

3. Flow meter of $\mathrm{H}_{2}$ and $\mathrm{He}$ 4. Evaporator

5. One-way valve 6. Solvent reservoir and burette
7. Pump
8. Reactor
9. Coal

10. Condenser

11. Glass trap

12. Soap film flow meter

Fig. 1 Schematic diagram of reaction apparatus

これに反して触媒を添加した場合の全転化率は無触 媒の場合に比較して 3 倍程度まで増加しているが，お のおのの反応は溶剤およびキャリヤーガスの種類によ って異なった挙動を示している。ただし塩化錫を触媒 とした実験では無溶剂の場合でも，全ガス状生成物収 率が無触媒反応の場合と同様なのに対して抽出物収率 は約 7 倍以上に増えている。すなわら脱アルキル基反 応を伴った解重合反応が触媒と水素の存在によって加 速されるものと考学られる。いずれの場合でもキャリ ヤーガスを水素からへリウムに換えると転化率が低下 して扣り, 水素の存在が触媒の活性化に重要な働きを していることがわかる。

おのおのの反応例に注目すると，トルエンを溶剂と して用いた場合，ガス状生成物中に数\%の $\mathrm{C}_{2}$ 㧊よび $\mathrm{C}_{3}$ 炭化水素の生成が 認められ 液状生成物中にはクレ オソート，キシレンおよびフェノール誘導体が検出さ れた。ベンゼンの生成量は無触媒反応に比較して極端 に増加して扣らず, トルエン自身の分解反応が加速さ れるよりも石炭の分解反応から生成する各種ラジカル を安定化するための相手物質または水素供与体として の役割を果しているものと考えられる。

アルコール類の溶剤が反応系に存在する場合にはい ずれも高い反応性を示し, 触媒の添加によって特に高 い液生成率を示している。同時にアルコール自身の分 解反応子触媒の添加によって促進されて敃り Table 2 に示すよらに反応残渣から算出された全転化率より 
Table 2 Semicritical gas extraction of Forestburg coal at $350{ }^{\circ} \mathrm{C}$ under $6.8 \mathrm{Kg} / \mathrm{cm}^{2} \cdot \mathrm{G}$

\begin{tabular}{|c|c|c|c|c|c|c|}
\hline Catalyst & solvent & $\begin{array}{c}\text { Carrier } \\
\text { Gas }\end{array}$ & $\begin{array}{c}\text { Total } \\
\text { Conversion } \\
(\text { wt } \%)\end{array}$ & $\begin{array}{l}\text { Gas } \\
\text { Yield } \\
(\text { wt } \%)\end{array}$ & $\begin{array}{c}\text { Extraction } \\
\text { Yield } \\
(\text { wt } \%)\end{array}$ & $\begin{array}{c}\text { Extract/ } \\
\text { Gas Ratio } \\
\text { (wt/wt) }\end{array}$ \\
\hline no & no & $\mathrm{He}$ & 12.7 & 10.5 & 2.2 & 0.21 \\
\hline no & no & $\mathrm{H}_{2}$ & 11.9 & 8.8 & 3.1 & 0.35 \\
\hline no & Toluene & $\mathrm{He}$ & 9.4 & 12.4 & 1.9 & 0.15 \\
\hline no & Toluene & $\mathrm{H}_{2}$ & 9.3 & 9.8 & 3.6 & 0.37 \\
\hline no & $\mathrm{CH}_{3} \mathrm{OH}$ & $\mathrm{He}$ & 9.3 & 16.2 & 1.0 & 0.06 \\
\hline no & $\mathrm{CH}_{3} \mathrm{OH}$ & $\mathrm{H}_{2}$ & 6.5 & 22.9 & 6.9 & 0.30 \\
\hline no & $\mathrm{C}_{3} \mathrm{H}_{7} \mathrm{OH}$ & $\mathrm{He}$ & 12.5 & 15.8 & 3.2 & 0.20 \\
\hline no & $\mathrm{C}_{3} \mathrm{H}_{7} \mathrm{OH}$ & $\mathrm{H}_{2}$ & 11.7 & 16.7 & 7.2 & 0.43 \\
\hline $\mathrm{SnCl}_{2} \cdot 2 \mathrm{H}_{2} \mathrm{O}$ & no & $\mathrm{H}_{2}$ & 32.3 & 10.9 & 21.4 & 2.0 \\
\hline $\mathrm{ZnCl}_{2}$ & Toluene & $\mathrm{He}$ & 17.2 & 11.5 & 1.4 & 0.12 \\
\hline $\mathrm{SnCl}_{2} \cdot 2 \mathrm{H}_{2} \mathrm{O}$ & Toluene & $\mathrm{He}$ & 21.0 & 10.4 & 1.9 & 0.19 \\
\hline $\mathrm{ZnCl}_{2}$ & Toluene & $\mathrm{H}_{2}$ & 30.3 & 7.8 & 14.9 & 1.9 \\
\hline $\mathrm{SnCl}_{2} \cdot 2 \mathrm{H}_{2} \mathrm{O}$ & Toluene & $\mathrm{H}_{2}$ & 43.5 & 14.9 & 18.3 & 1. 2 \\
\hline $\mathrm{SnCl}_{2} \cdot 2 \mathrm{H}_{2} \mathrm{O}$ & $\mathrm{CH}_{3} \mathrm{OH}$ & $\mathrm{He}$ & 14.3 & 40.1 & 5.6 & 0.14 \\
\hline $\mathrm{ZnCl}_{2}$ & $\mathrm{CH}_{3} \mathrm{OH}$ & $\mathrm{H}_{2}$ & 40.1 & 22.6 & 26.1 & 1.2 \\
\hline $\mathrm{SnCl}_{2} \cdot 2 \mathrm{H}_{2} \mathrm{O}$ & $\mathrm{CH}_{3} \mathrm{OH}$ & $\mathrm{H}_{2}$ & 31.2 & 57.0 & 48.3 & 0.85 \\
\hline $\mathrm{SnCl}_{2} \cdot 2 \mathrm{H}_{2} \mathrm{O}$ & $\mathrm{C}_{2} \mathrm{H}_{5} \mathrm{OH}$ & $\mathrm{He}$ & 11.4 & 23.5 & 43.7 & 1.9 \\
\hline $\mathrm{SnCl}_{2} \cdot 2 \mathrm{H}_{2} \mathrm{O}$ & $\mathrm{C}_{2} \mathrm{H}_{5} \mathrm{OH}$ & $\mathrm{H}_{2}$ & 42.6 & 14.9 & 37.5 & 2.5 \\
\hline $\mathrm{SnCl}_{2} \cdot 2 \mathrm{H}_{2} \mathrm{O}$ & $\mathrm{C}_{3} \mathrm{H}_{7} \mathrm{OH}$ & $\mathrm{He}$ & 29.3 & 29.2 & 14.0 & 0.48 \\
\hline $\mathrm{ZnCl}_{2}$ & $\mathrm{C}_{3} \mathrm{H}_{7} \mathrm{OH}$ & $\mathrm{H}_{2}$ & 32.4 & 36.5 & 17.4 & 0.48 \\
\hline $\mathrm{SnCl}_{2} \cdot 2 \mathrm{H}_{2} \mathrm{O}$ & $\mathrm{C}_{3} \mathrm{H}_{7} \mathrm{OH}$ & $\mathrm{H}_{2}$ & 32.8 & 24.5 & 13.4 & 0.55 \\
\hline
\end{tabular}

Table 3 Elementary analyses of products and structural parameters of extracts

(Reaction temperature : $350^{\circ} \mathrm{C}$, Pressure of hydrogen $: 6.8 \mathrm{Kg} / \mathrm{cm}^{2} \cdot \mathrm{G}$ )

\begin{tabular}{|c|c|c|c|c|c|c|c|c|c|c|c|}
\hline \multirow[b]{2}{*}{ Catalyst } & \multirow[b]{2}{*}{ Solvent } & \multicolumn{7}{|c|}{ Extract } & \multicolumn{3}{|c|}{ Residue } \\
\hline & & $\begin{array}{c}\text { C } \\
\text { (daf }\end{array}$ & $\begin{array}{c}\mathrm{H} \\
\%)\end{array}$ & $\begin{array}{l}\mathrm{H} / \mathrm{C} \\
\text { Atomic } \\
\text { Ratio }\end{array}$ & $\mathrm{f}_{\mathrm{a}}$ & $\mathrm{Hau} / \mathrm{Ca}$ & $\sigma$ & $\mathrm{f}_{\mathrm{a}} *$ & $\begin{array}{c}C \\
\text { (daf }\end{array}$ & $\begin{array}{c}\mathrm{H} \\
\text { wt } \%)\end{array}$ & $\begin{array}{l}\mathrm{H} / \mathrm{C} \\
\text { Atomic } \\
\text { Ratio } \\
\end{array}$ \\
\hline no & Toluene & & & & & & & & 73.4 & 3.8 & 0.62 \\
\hline no & $\mathrm{CH}_{3} \mathrm{OH}$ & 75.3 & 9.3 & 1.5 & 0.36 & & & & 75.4 & 4.6 & 0.72 \\
\hline no & $\mathrm{C}_{3} \mathrm{H}_{7} \mathrm{OH}$ & 74.9 & 9.3 & 1.5 & & & & & 76.0 & 4.5 & 0.70 \\
\hline $\mathrm{SnCl}_{2} \cdot 2 \mathrm{H}_{2} \mathrm{O}$ & no & 85.7 & 7.5 & 1.0 & 0.65 & 0.87 & 0.39 & 0.61 & 70.8 & 4.8 & 0.80 \\
\hline $\mathrm{ZnCl}_{2}$ & Toluene & 82.3 & 7.9 & 1.1 & 0.59 & 0.89 & 0.52 & 0.59 & 64.5 & 4.4 & 0.81 \\
\hline $\mathrm{SnCl}_{2} \cdot 2 \mathrm{H}_{2} \mathrm{O}$ & Toluene & 82.6 & 8.0 & 1.2 & 0.57 & 0.90 & 0.47 & 0.58 & 76.0 & 5.0 & 0.78 \\
\hline $\mathrm{ZnCl}_{2}$ & $\mathrm{CH}_{3} \mathrm{OH}$ & 71.0 & 7. 3 & 1.2 & 0.55 & 0.89 & 0.48 & 0.49 & 66.2 & 4.5 & 0.81 \\
\hline $\mathrm{SnCl}_{2} \cdot 2 \mathrm{H}_{2} \mathrm{O}$ & $\mathrm{CH}_{3} \mathrm{OH}$ & 70.3 & 7.6 & 1.3 & 0.54 & 0.92 & 0.43 & 0.47 & 75.7 & 5.1 & 0.80 \\
\hline $\mathrm{SnCl}_{2} \cdot 2 \mathrm{H}_{2} \mathrm{O}$ & $\mathrm{C}_{2} \mathrm{H}_{5} \mathrm{OH}$ & 76.3 & 8.2 & 1.3 & & & & & 75.2 & 4.9 & 0.78 \\
\hline $\mathrm{ZnCl}_{2}$ & $\mathrm{C}_{3} \mathrm{H}_{7} \mathrm{OH}$ & 71.1 & 7.5 & 1.3 & 0.58 & 0.89 & 0.41 & 0.59 & 64.8 & 4.3 & 0.79 \\
\hline $\mathrm{SnCl}_{2} \cdot 2 \mathrm{H}_{2} \mathrm{O}$ & $\mathrm{C}_{3} \mathrm{H}_{7} \mathrm{OH}$ & 75.3 & 7.9 & 1.2 & & & & & 77.4 & 5.2 & 0.81 \\
\hline SRC** & & & & & 0.69 & 0.93 & 0.55 & & & & \\
\hline
\end{tabular}

$\mathrm{f}_{\mathrm{a}} \quad:$ Fraction on aromatic carbons per average molecule

$\mathrm{f}_{\mathrm{a}} * \quad: \mathrm{f}_{\mathrm{a}}$ calculated from ${ }^{1} \mathrm{H}-\mathrm{NMR}$ and elementary analysis

$\mathrm{Hau} / \mathrm{Ca}:$ Atomic hydrogen to carbon ratio of the hypothetical unsubstituted aromatic nuclei

$\sigma \quad$ : Degree of substitution of the aromatic system

SRC** : SRC produced by autoclave experiment 
も，ガスおよび液生成率の合計が見かけ上大きくなっ ている。本研究の実験範围ではメチルアルコールを溶 㑉とし，塩化錫を触媒として水素加圧下で反応させた 場合に最高の転化率 $48.3 \mathrm{wt} \%$, また最高の生成物中 の液/ガス構成比はエチルアルコールを用いた場合で 2.5を得ている。

抽出物扣よび残渣の元素分析値敊よび $\mathrm{H} / \mathrm{C}$ 原子比 （Table 3）によるとアルコール系溶剤を用いた場合 には類似しており，その抽出物はトルエン溶剤の場合 より若干水素含有量が高く, 触媒反応で得られた残渣 はいずれの場合でも同程度の $\mathrm{H} / \mathrm{C}$ 值を示し，法とん ぞ原料炭と同じか多少水素含有量の増光た性状であっ た。これに対して無触媒反応で得られた抽出物は, そ の収率は低いものの $\mathrm{H} / \mathrm{C}$ 值がほぼ 1.5 と触媒反応の ものより大きく，石炭中の軽質部分のみが抽出物とし て取り出されたことを示している。ただし残渣につい ては反応系に添加する水素の有無に関係なく，その $\mathrm{H} / \mathrm{C}$ 值は0. 6 0.7と低く軽質部分を放出した残渣に 水素が取り込をれる可能性は少ないことを示してい る。

各種反応によって得られた抽出物の構造解析データ

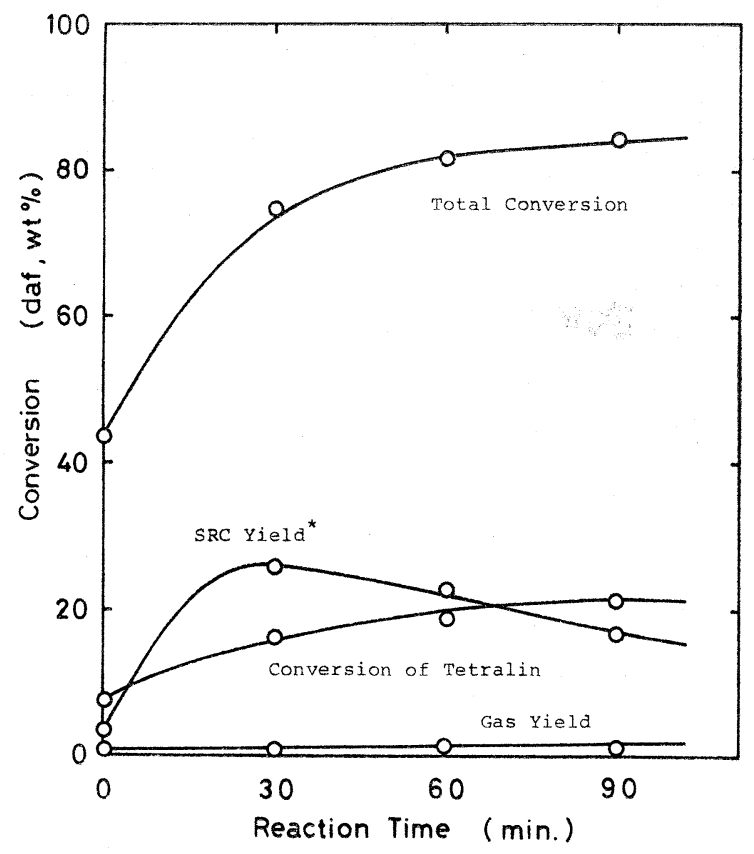

*Conversion of tetralin to naphthalene, methylindane and decalin (mol.\%)

Fig. 2 Liquefaction of Forestburg coal at $420^{\circ} \mathrm{C}$, under $51 \mathrm{~kg} / \mathrm{cm}^{2} \cdot G$ of hydrogen and tetralin/coal weight ratio of about 5
をTable 3 と付記した。解析はおすに $\mathrm{CDCl}_{2}$ を測定 溶媒とした ${ }^{13} \mathrm{C}-\mathrm{NMR}$ 扮よび一部 ${ }^{1} \mathrm{H}-\mathrm{NMR}$ スペクト ロメータにより, 各種パラメータの算出は BrownLadner 法》) の概念に基づいた。結果によると得られ た芳香族性指数（fa）の值は全体的に 0.6 以下と低く, 平均的な構造は芳香族化合物と同等またはそれ以上の 脂肪族化合物を含む比較的軽質なものと理解される。 触媒および溶剤の共存した実験から得られた抽出物の fa值は無触媒の場合のそれに比較して一段と大きく, Table 2 に示したように後者ではガス生成率が大き く液生成率が前者に比べて小さいことを考光合わせる と, 無触媒反応で得られた液生成物は汪とんど脂肪族 化合物またはベンゼンに長い側鎖岁るいは脂環構造物 が結合した化合物拉よびその混合物で, 熱反応によっ て比較的容易飞石炭から解離するものと推測出来る。 触媒反応で生成した抽出物については，溶剤存在下で 得られたもののfa值が無溶剤のそれよりも低く, 溶剤 の存在によって若干の軽質化反応が進行している。

さらに芳香族系として州属された炭素について, 吉 田らの方法 ${ }^{8)}$ により ${ }^{13} \mathrm{C}-\mathrm{NMR}$ スペクトログラムにつ いて詳細な構造の解析を試みた。すなわち比較的分離 性の明確な抽出物のデータを選択し, 芳香族炭素 をいわゆる Profonated, Bridge head および Substituted Carbon 飞䚻属させ，芳香族縮合度 ( $\mathrm{Hau} / \mathrm{Ca})$ 特よび芳香族環の置換指数 ( $(\sigma)$ を算 出した。測定方法怙よび解析方法についてはかな りの不確定な要素があり結果の評価には十分気を 付けねばならないが，溶剤の存在しない場合の $\sigma$ 值が若干低いものの $\mathrm{Hau} / \mathrm{Ca}$ 值は約 0.9 であり, 抽出された成分の構造単位はベンゼンまたはナフ タレン環芳香族化合物を基礎としていることが推 測される。なお Table 3 と付記した ${ }^{1} \mathrm{H}-\mathrm{NMR}$ 解 析と元素分析倡より計算されたfa值は全体的に良 好な一致を示した。

本研究では Forestburg Coal の基本単位構造 について, 異なった方式の実験結果からも比較, 検討するため通常のオートクレーブによる液化反 応もあわせて試みた。実験は $300 \mathrm{~m} l$ 電磁攪找式オ ートクレーブにより，60mesh 以下に粉碎した石 炭約 17 g とテトラリン約 $83 \mathrm{~g}$ （テトラリン/石炭 重量比約 5 ）とを混合し, 反応温度 $420 \pm 1.5^{\circ} \mathrm{C}$, 水素初圧 $51 \mathrm{~kg} / \mathrm{cm}^{2}$ ・ G の条件下で行われた。反応 生成物をろ過法によって分離, さらにトルェンで 洗浄後, 乾燥して得られた残渣の重量に基づいて 全転化率を算出した。ガス状, 液状扣よび固体状 
生成物の回収率は $93 \%$ 以上であった。減圧蒸留によっ てテトラリンを除いて得られた S R C の生成率, ガス 生成率怙よび全転化率の経時変化をテトラリンの反応 率とともにFig. 2 に示した。テトラリンからの反応生 成物は 80 90wt\% がナフタレンであり，他にメチル インダン, デカリンなどが検出され, 反応の経過とと もにナフタレンへの反応率は低下している。テトラリ ン不溶物によって反応の転化率を評洒したため, トル エンのソックスレー抽出に基づいて評価した臨界ガス 抽出法の結果とは必ずしも直接の比較は出来ないが, オートクレーブ実験の場合, ガス生成率はいずれの実 験でも $1.5 \mathrm{wt} \%$ 以下と低く, 逆に液化反応性は高か った。反応によって得られたS R C について前記と同 様の手法に基づき構造パラメータの解析を行い, 結果 をTable 3 亿付記した。S RCのfa, Hau/Ca および $\sigma$ の值はいずれも若干高いが，やはり基本単位構造に ついては臨界ガス抽出法の場合と類似の結論が得られ た。

本研究はカナダ・アルバータ州産の代表的な亜派青 炭をとりあげ，臨界ガス抽出法敊よび通常のオートク レーブによる実験を試み，その液化反応性および化学
構造についての概略的知見を得るために行われたもの であり，今後豊富な石炭資源であるいわゆるカナダ・ 西部炭について，広範な反応条件下での実験研究を進 める必要があろう。

\section{文献}

1) Alberta Coal(Alberta Economic Development, Energy \& Natural Resources, 1981)

2) Reserves of Coal-Province of Alberta, 1980 (Energy Resources Conservation Board)

3) Gangoli, N. and Thodos, G., Ind. Eng. Chem., Prod. Res. Dev., 16, 208 (1977)

4) Bartle, K., Martin, T. G. and Williams, D. F.,Fuel, 54, 226 (1975)

5) Bartle, K., Ladner, W. R., Martin, T. G., Snape, C. E. and Williams, D. F., ibid., 58, 413 (1979)

6) Mortimer, J., ibid., 59, 782 (1980)

7) Brown, J. K. and Ladner, W. R., ibid., 39, 87 (1960)

8）吉田忠, 前河涌典, 内野洋之, 横山普, 第16回石 炭科学会議発表論文集, p. 139 (1979) 


\title{
Study on the Liquefaction Behavior and the Chemical Structure of Alberta Coal, Canada
}

\author{
Yoshiki SATo and Sujit K. ChakrabartTy* \\ $\left(\begin{array}{l}\text { National Research Institute for Pollution \& Resources, } \\ \text { *Alberta Research Council, Canada }\end{array}\right)$
}

SYNOPSIS:-Liquefaction behavior and chemical structure of Alberta coal, Canada have been evaluated by semicritical gas extraction and conventional autoclave experiment. The effects of catalyst $\left(\mathrm{ZnCl}_{2}, \mathrm{SnCl}_{2} \cdot 2 \mathrm{H}_{2} \mathrm{O}\right)$ and solvent (toluene, $\mathrm{CH}_{3} \mathrm{OH}$, $\left.\mathrm{C}_{2} \mathrm{H}_{5} \mathrm{OH}, \mathrm{C}_{3} \mathrm{H}_{7} \mathrm{OH}\right)$ on the gas extraction have been observed using a small high pressure flow apparatus near critical conditions with or without hydrogen. Conversion to gas and liquid increased strikingly in the presence of hydrogen up to $43 \mathrm{wt} \%$ and the weight ratio of liquid to gaseous product also increased with the addition of catalyst and solvent.

Autoclave experiments were carried out in a $300 \mathrm{ml}$ conventional autoclave equipped with a stirring device at $420{ }^{\circ} \mathrm{C}$ under $51 \mathrm{Kg} / \mathrm{cm}^{2} \cdot \mathrm{G}$ of hydrogen in the presence of 5 parts of tetralin. Conversion calculated on the basis of tetralin insoluble were observed up to $85 \mathrm{wt} \%$.

The structural parameters of the extracts obtained from both types of reactions were evaluated by the modified Brown-Ladner's equation. From average $\mathrm{f}_{\mathrm{a}}$ of 0.6 and $\mathrm{Hau} / \mathrm{Ca}$ of 0.9 , an average unit cluster has been estimated to be the mixture of one or two aromatic rings which are joined together with some saturate groups.

\section{Key Words}

Alberta coal, Critical gas extraction, Coal structure 